loans which the company is expected to secure from the banks. Help is also to be provided for ICL's research and development programme which last year consumed about 8 per cent of the company's £715 million turnover.

Sir Keith's intervention is seen as a major blow to the Conservative government's policy of not interfering in private industry. But the decision was taken only after several months of searching for private investors had found no takers. The chief justification for supporting ICL when other private industries are allowed to go to the wall seems to be that the smooth operation of many government offices depends heavily on its computers.

ICL is something of a favourite of British governments. When it was created in 1968 from the amalgamation of two computer companies, the government retained a substantial shareholding and supported it heavily during its early years both with cash and with awards of almost all contracts for large computers for government departments. In the 1970s, the company became profitable and in late 1979, Mrs Thatcher's government sold off its shares. But only 18 months later, ICL's profits took a lurch.

Precisely why the company's fortunes changed so suddenly seems to be a mystery. The company itself says that the world recession combined with the strong value of the pound and high interest rates is responsible. There were hints of trouble, it says, in the first half of 1980 but during the second half both home and overseas orders fell off markedly. Others have said that poor management, a concentration on large computers when the market is moving towards desk-top machines, spending too much on parts of the business not connected with manufacturing and even underpricing goods, are also responsible.

Neither the government nor the banks, however, seem to have stipulated conditions for the $£ 200$ million loan. The company hopes to ride out the recession by continuing business much as before and economizing wherever possible. It says, for example, that its research and development programme will continue at much the same level as last year, with the same mix of research on large and small machines. One of the projects on which it pins hopes for the future is the large Distributed Array Processor which has so far been sold to the British National Oil Corporation, for seabed exploration, and Queen Mary College University of London. The Science Research Council is considering buying one for its Rutherford or Daresbury laboratories.

Sir Keith Joseph hopes that the government will not have to make good its guarantee, believing that the loan will see ICL through the recession until business picks up again. Meanwhile, the net is still being cast far and wide in the hope of finding private investment on suitable terms.

Judy Redfearn
London medical schools Mergers galore

The University of London has made a modest beginning on the reorganization of its twelve medical schools. Last week, the senate of the university approved a plan to save something like $£ 5$ million a year, or ten per cent of the present cost to the university of medical education. Some two-thirds of the saving will come from a general reduction of staff-student ratios throughout the medical schools.

The accompanying reorganization of the London medical schools is only a pale shadow of the grand design put forward more than a year ago by a committee under Lord Flowers, rector of Imperial College. At the senate meeting last week, it was formally agreed that the Westminister Hospital Medical School (a clinical school now recruiting about 100 students a year) should be merged with the medical schoo at Charing Cross Hospital (now located in West London). Other proposed groupings of medical schools have been given until later in the year to work out how they will coordinate their teaching.

The Westminster school considers itself unfairly singled out by these developments. Ever since the publication of the Flowers Report, Westminster has been urging the benefits of small medical schools, complaining that its students or their successors will be lost in a medical school with an annual intake of 180 , the planning figure for clinical students at Charing Cross. It also says that the efforts that have been made in the past year or so to coordinate teaching between the two hospitals may be jeopardized by the shotgun marriage now decreed. Given forward commitments to students, it may be as much as five years before teaching comes to an end on the Westminster site.

In retrospect, the schools least affected by the changes now proposed are those at Guy's Hospital and St Thomas's Hospital, which announced last year that they would form a joint school, with a single governing body, but would continue to operate on both the present sites. This arrangement has now been sanctioned by the university senate. The other consortia from which the university is seeking financial savings are University College, Middlesex and St Mary's, which are required between them to save the equivalent of one clinical and one preclinical school; St Bartholomew's and the London Hospital, which have been given until June to suggest how they will merge; and King's College (which has a preclinical school) and King's College Hospital, which seem to be willing to fall in with the recommendation that they should form an integrated unit.

The proposals accepted last week by the senate were recommended by the Joint Planning Committee on Medical Education, set up to pilot the Flowers Report through the university. In the past year, and especially as a result of a detailed analysis of the costs of the London medical schools carried out by a firm of accountants, it became clear that changes of staffstudent ratios offered the most rapid route to cost reductions. The committee accepts as a standard for future staffing a ratio of $1: 10$ for preclinical schools and 1:7 for clinical schools. This would mean the loss of 180 academic posts, which it is hoped can be achieved by natural retirement and wastage in the next five or six years.

Running through the report of the joint committee is the view that medical education should be concentrated in larger units than at present, especially where modern buildings have been provided. In this spirit, the committee recommends that the development of the St George's Hospital site in South London should be continued. The future of the postgraduate medical institutes remains entirely open, however. With the exception of the Institute of Dermatology (which is to merge with St Thomas's Hospital Medical School), the institutes have been seriously affected by the reductions in the past year in the numbers of overseas students. The university is hoping that central government will help bail them out, but no decision has yet been reached.

Last week's decision by the university senate is likely to be regarded, within the University of London, as some kind of precedent for the reorganization of the non-medical parts of the university likely to be recommended by the Swinnerton-Dyer committee, due to report in September, and elsewhere as a sign that, if pressed hard, even British universities can change their ways.

\section{Law of the Sea}

\section{US backtracks}

\section{Washington}

The Reagan Administration's decision to carry out a complete review of the US position on the draft Law of the Sea Treaty, now under discussion at the United Nations in New York, indicates that significant new attitudes may emerge towards international resource disputes ranging from the surface of the Moon to the minerals of the Antarctic continent.

The United States is considering whether to adhere to the concept that natural resources which lie outside the immediate political domain of individual nations should be treated as "the common heritage of mankind" - a term coined by the United Nations - or whether, in the name of free enterprise and the national security implications of a shortage of strategic minerals such as cobalt and manganese, this concept should be abandoned, together with attempts to set up international regulationsto control exploitation.

A new twist to the Law of the Sea negotiations comes from the likely take-over of the Kennecott Corporation, a leading critic 